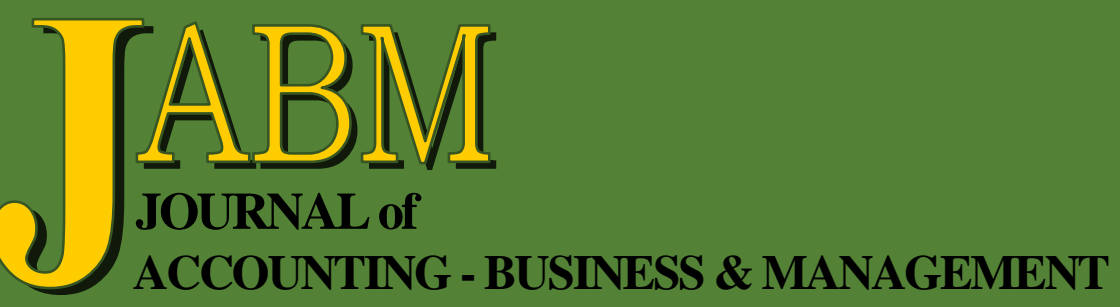

Individualism versus Collectivism Orientation as Moderator between Co-Workers' Social Support and Work to Family Enrichment

Aneel Kumar, Khalil Ahmed Channa and Muhammad Waqas Maharvi

Strategic Alliances in Knowledge-Intensive Industries: An Integrated View

Yongliang Stanley Han and Xiang Liu

Strategic Investment Decisions: An Empirical Study of Power Sector in India

Santosh Phulpagar, Koilakuntla Maddulety, Srinath Jagannathan, and Shalini Kalia

The Design of a Web-Based Program for Reporting Incomes Tax Article 21 for Civil Servants

Damayanti and Tri Sandhika Jaya

The Deceitfulness of Sticky Costs on Banking Systems

César Vela-Beltrán-del-Río and Luis Felipe Llanos Reynoso 
Journal of Accounting - Business \& Management vol. 25 no. 2 (2018) 61-80

\title{
The Deceitfulness of Sticky Costs on Banking Systems
}

César Vela-Beltrán-del-Río*

Luis Felipe Llanos Reynoso ${ }^{\dagger}$

\begin{abstract}
Understanding the true, sometimes deceitful, nature of sticky costs is vital to take advantage of market opportunities and to compete; by aligning the needed substructure to the medium and long term business expectations. Doing so will allow management to be better positioned to achieve such goals. This long-term research (16 years), performed in México, offers a holistic understanding of the real sticky costs behavior in both bullish and bearish markets. The stickiness nature of costs is an unintended manifestation of the embedded conditions of the assets acquired, while pursuing longer term objectives. This is the case because it is through assets, in general, that businesses compete. We will document that costs behave differently in bearish and bullish markets; costs, under general market conditions, perform at different rates in each market. We introduced a dummy regression variable to determine if the increase in administrative spending is positively related to an income increase, considering years with income increases and decreases. We also found that costs will continue rising, at a lower rate, even in bearish markets, unless there is a global crisis. Those who not understand the actual sticky nature of costs will face their deceitful nature, especially during bearish markets.
\end{abstract}

Keywords: Mexican banking system, bearish and bullish markets, management, competitive assets, cost behavior, financial crisis.

\section{INTRODUCTION}

\subsection{The Significance of the Sticky Cost Analysis}

Basically, until the end of the 20th century, scholars and top management assumed that costs and expenses would mirror income's changes. However, that is no longer accurate (Anderson et al., 2003). Labeling costs and expenses as fixed or variable, relative to income changes is not relevant either. The efficient management of costs and expenses is essential because of the expected improved result; which occurs as a result of accurately matching costs and expenses to income, translating into efficiencies. Enhanced understanding of the cost structure and what are the resources used for, along with their acquiring conditions, leads to a better cost/expense control and decisions. This is especially the case when management needs to be aware of which part of the resources paid for goes unused (Cooper \& Kaplan, 1992). Misunderstanding the sticky nature of selling and administrative costs leads to inadequate management decisions. Furthermore, traditional cost and financial accounting and/or analysis, for insiders and external analysts, respectively, does not accurately depict the complete nature of the selling and administrative expenses (Cooper \& Kaplan, 1992); thus, establishing that there is a lot more to this than merely allocating them as fixed or variable, as related to the output level. For instance, altering the capacity involves larger

\footnotetext{
* Corresponding Author. Facultad de Economía y Negocios, Universidad Anáhuac México. Huixquilucan, Estado de México, México. E-mail: cesar.vela@anahuac.mx.

† Facultad de Economía y Negocios, Universidad Anáhuac México, Huixquilucan, Estado de México, México. E-mail: luis.llanos@anahuac.mx.
} 
adjustments, which translate into cost stickiness, more than merely reducing the capacity of the support departments (Balakrishnan \& Gruca, 2008). That is why those responsible for the critical business-related decisions must be aware cost stickiness, especially in a global economy where competition is vicious and there is no space for errors and/or deficiencies.

Even though the literature calls it cost stickiness, we prefer to differentiate costs from expenses. For us, costs are related to the production level or offering a service. On the other hand, expenses are somehow unrelated to it, since expenses are relatively "fixed" to a certain production level. In the case of banks, costs are basically the rate paid for the financial resources channeled to borrowers. Expenses in general relate to administrative labor, services used, other "fixed" resources and/or assets, and/or depreciation and/or amortization, among others. The expenses reported by the Mexican banks are administrative, promotion, and sometimes other expenses (CNBV, 2017).

While anticipating the demand for their products and/or services, executives allow certain level of expenses to support both the output and demand levels; this is not independent from the production or output level established. In other words, expense levels must support the output and demand levels. As output and demand levels change, expenses must follow; otherwise, there will be an insufficient expense substructure to support an output and demand level or excessive expenses, some of which will be wasted. Excess demand, to the anticipated, can sometimes be met in the short term with an additional expense allocation, in the form of additional resources to increase the responsiveness and/or the aggregate offered, for instance (Chopra \& Sodhi, 2004). However, excessive expense levels are not conducive to the actual output and demand levels, meaning more expenses than actually required. This carries inefficiencies and additional expenses for the organization that translate in lower profitability, inefficiencies, and reduced cash flow.

Nonetheless, in an attempt to balance income and expenses, managers rely on accurate forecasts; which for many global wide organizations, are not necessarily common and therefore a source of additional risk that is an integral part of doing business, for such institutions, with all its consequences (Fisher et al., 1994). We highlight that accurate forecasts are difficult to access, especially in the developing world where México is an example.

\subsection{Research Importance}

Analyzing cost stickiness is important because expenses do not move as income does, as previously considered. Furthermore, cost stickiness is in itself a relevant, important topic because management needs to able to control it correctly for competition purposes; this is specially the case during the current dynamic times. Understanding and managing cost or expense stickiness is a major managerial skill, especially facing bearish markets simply because the stickiness can affect the company's profitability and competitiveness. Managing the stickiness factor properly requires trading off the medium and long term essential investments to compete with the current year's bottom line.

\section{THEORETICAL BACKGROUND}

Cost stickiness describes the effect of an income change, which can either be positive or negative, on the change of selling and administrating expenses, where the income change is larger than the one suffered by the expenses (Anderson et al., 2003). In other words, the stickiness concept describes that expense reductions are normally 
smaller than income reductions. Yet, it is important to notice that the slope' increments are different from the slope's decrements (Anderson et al., 2003). Income increase markets are considered bullish and income decrease markets are considered bearish; market performance and expectations have important repercussions on the required substructure and therefore cost stickiness. For instance, Calleja et al. (2005) identified that operating costs increases during market increases or bullish markets $(0.97 \%$ per $1 \%$ income increases), are larger than expense decreases, during bearish markets $(0.90 \%$ per $1 \%$ income decreases), for a set of American, British, French and German companies. However, Anderson et al. (2003) found in a large firm sample that expenses grow at $0.55 \%$ (per $1 \%$ income increase), while expenses decrease at $0.35 \%$ (of $1 \%$ during income decreases). Under normal situations, the stickiness effect negatively impacts the bottom line because expenses do not get as smaller as income does; some resources are wasted too. In bearish markets, the expenses are larger than what is actually needed. Thus, expenses do not shrink as income does and translates into excess expenses for a particular level of output -leading to the lower bottom line. The risk of this type of situations represents higher expenses and payments and a decrease in cash flow, liquidity, and return - while increasing the business' risk. In extreme situations, global competition might compromise the longevity of the company. For example, banks during bearish markets experience cost stickiness additionally to higher interest and default rates. Therefore, there is a deceitful nature to sticky costs that might not be instinctive for all managers. Most would think that expenses can be modified at will when this is actually far from the truth. Usually, expenses are budgeted in at least a year in advance to create the needed substructure.

On the other hand, during bullish markets, management attempts to keep up with demand. An additional expense allocation might solve the issue, rapidly and trouble free. In this situation, the risk is significantly reduced because management is reacting to reality, rather than anticipating a potential event. In the case of lower than anticipated demand, the additional sales balance off the extra expenses. This is not the optimal situation for a corporation, as might be the case during bearish markets because additional income offsets additional expenses (even though this is a "normal practice," it shouldn't be because the new to additions to the substructure might become part of sticky costs in the near future). With accurate demand predictions, expense levels support efficiencies. Yet, the nature of the sticky costs does not support businesses' efficiencies and that is why executives must stay alert.

Forecasting is an important tool for any decision - making allocation process (Pagan, 2003), as is cost analysis for efficient business; yet, management must also be aware of the additional costs related to altering, whenever possible, the previously selected level of selling and administrative expenses based on the real output and demand (Balakrishnan \& Gruca, 2008). The same authors theorized that not all areas present the same level of stickiness; these are the strategic aspects of managing costs. The reasons for the stickiness effect, when expenses are reduced at a lower rate than the rate at which income decreases, are among others, mainly related to the people costs (Balakrishnan \& Gruca, 2008). If management is not familiar with resource acquisition, including their conditions, we argue that assets related expenses are also a stickiness factor. Examples of people-related expenses are severance/termination payments. Some authors even include "the costs of searching for, hiring, and training employees" (Balakrishnan \& Gruca, 2008). On the other hand, some examples of assetrelated costs are: rent and the related rent period and/or purchase of real estate or 
property in general, the required adaptations, among many others. Both people and asset related expenses will have an effect on the sticky cost behavior.

\subsection{Sticky Costs and their History}

During the 80's and 90's, management realized that the traditional cost systems, those who used volume-driven expense allocation, did not provide the whole picture, or an accurate one, especially when there are applied and available resources not related to the output and demanded volume (Cooper \& Kaplan, 1992). The variable vs. fix costs traditional cost approach was not enough to appropriately manage enterprises. For that reason, management needed to develop systems that better described the real expense driver. At that time, Activity - Based Cost Systems (ABC) were developed to calculate the cost of all the resources used to run the corporation, including processes and output (Cooper \& Kaplan, 1992). This system provided an estimate of the costs related to the unused capacity, as the same authors point out. ABC filled the gap of traditional cost systems, linking costs or activities to products and, probably more importantly, measuring the cost of the unused capacity. A decade later, sticky cost analysis, likewise, complemented the information provided by traditional cost systems and $\mathrm{ABC}$, proving that expenses cannot be changed at the same rate as income does (Anderson et al., 2003). There are additional benefits, for management, derived from the use of other complementary costing systems, which are beyond the scope of this current research paper.

\subsection{History of Banks' Sticky Costs}

We could not find a wide variety of papers addressing sticky costs in Latin America's banking systems. In fact, we were looking for research papers addressing banks' sticky cost behavior in the mentioned region to compare these practices with those of the Mexican banking system. Porporato and Werbin (2010) discuss their findings in Argentina, Brazil and Canada, in the years 2004 to 2009. They concluded that recognizing the nature of costs is vital to managing businesses, in the short and medium terms cost stickiness is higher than in the long term because managers delay the necessary actions. It is vital to highlight that they found cost stickiness evidence in such markets, just as we did in the Mexican banking market. Furthermore, these same authors consider the present situation in Mexico as a result of inadequate management decisions trade[ing] off between the cost of having idle capacity and the cost of exit and replacement of the resources being disposed off (Porporato \& Werbin 2010, p. 22).

The other relevant paper found was Werbin (2011) that analyzed the Argentinean banks from 2005 to 2007. This author, who worked on both papers, reached the same conclusions that Porporato and Werbin (2010) did.

\subsection{Long-Term Management Perspective}

We do not believe that management, in general terms, is negligent or tardy in their actions; rather, we think that their medium and long-term perspective has to be very positive for costs to be sticky; otherwise management would act very conservatively and lease instead of buying or temporarily hiring human capital, and therefore reducing the magnitude of such expenses. Otherwise, as income decreases, top management would take the appropriate and needed actions as soon as required. Management does not only look at the year's bottom line but also to the medium and long term perspectives for competition purposes. We found evidence that management looks at a couple of years in relation to expenses. We believe that each company's management has available all of the information relevant and decides on the assets and conditions they book (Stímolo \& Luquez, 2015). Management would not book assets 
that would negatively impact the bottom line without a real purpose, for the longer term. For us, that is what really is behind the stickiness of costs. It can be through technology and organization (Aaker, 1989), economies of scale, differentiation, entry barriers, human capital and access to certain markets or distribution channels, for instance (Porter, 1985). Access to suppliers is also important. Total assets and equity, customer service and IT budgets and employees, total employees, company's age and number of products sold provide also competitive advantages (Ray et al., 2004). For Auletta (2015) equity provides a competitive edge. Management is investing in somehow "fixed" expenses since assets provide a competitive edge.

\subsection{The Financial Crises of the $21^{\text {th }}$ Century}

The 21 st century has not been immune to financial crises. Some have had important consequences locally and globally, sometimes even negatively impacting the entire global economy due to the current level of international financial integration throughout the world (Milesi-Ferretti \& Tille, 2011). Such financial crises produce negative impacts on the banks' bottom line; a situation that might be magnified due to cost's stickiness. In addition to the stickiness effect, banks suffer higher interest and default rates, and carry lower grade financial assets. Financial crises are usually felt to their fullest extent during bearish markets and the normal repercussions negatively impacting institutions, corporations, and people. Thus, cost stickiness is particularly dangerous.

However, it is important to notice that crisis do not behave as a normal distribution; [in] the upper and lower ends of the distribution ... [there] would be many more outlying events than statisticians ... would have imagined" (Gladwell, 2009, p. 72). [... even though] the bell-curve assumption has become so much part of our mental architecture that we tend to use it to organize experience automatically (Gladwell, 2009, p. 223)

In other words, a financial crisis does not behave as a normal distribution- it is an anomaly. "Man-made [events happen because someone did something that he or she was] not supposed to do" (Gladwell, 2009); therefore, such events should not had happened. An example of this is the Russian financial crisis:

[T] he Russians, by defaulting on their bonds, did something that they were not

supposed to do, an once-in-a-lifetime, rule-breaking event (Gladwell, 2009, p. 73).

The point here is to notice that in the financial markets rules cannot be followed, unlike what happens in the universe. Central banks can decide to default on government-backed securities (Gladwell 2009). Something that should not have happened either was the 2007-2008 global crises that started with mortgage backed securities issued in the United States. These securities were issued to individuals who did not have the minimal liquidity qualifications to repay the related mortgages; additionally such bonds were assigned, by rating agencies, a high grade - that did not disclose the real underlying risk. We will later relate back to these securities with greater detail. These examples basically mean that everything that can happen will happen: nothing is absurd enough and therefore we, as society, must be ready for basically everything because someone somewhere will not follow the established and accepted rules, producing the next financial crisis.

We covered the main financial crises of the $21^{\text {th }}$ century, which overlapped with our research, to describe the effect of such crises in the stickiness factor on the Mexican banks. We decided to differentiate how banks behave under normal 
conditions and under financial crises. This is important because the stickiness factor does not behave in the same way.

\subsubsection{1-2002 Argentine Economic Crises}

The 2001-2002 crises had its origins in a weak Argentine peso, fixed to the American dollar, until the local central bank was unable to continue supporting its currency and eventually producing a large, unexpected devaluation. The situation was not prevented since the International Monetary Fund (IMF) would not believe that the relevant and required reforms would take place, since Argentina was a defaulter; for this reason the IMF decided not to support Argentina this time. From our perspective, the Argentinean government thought it was too big to be let fail. This situation combined a currency crisis with financial panic when the local government froze the bank's deposits, among the local depositors; causing interest rates to rapidly increase. While the local and foreign families and enterprises could not access their savings, the inflation rate increased to approximately 5,000\%. Furthermore, the situation was overblown when the Argentine government and private financial institutions lost access to international capital markets, while foreign banks pulled out of the country. By 2002, the situation of the local debtors was extremely difficult, many businesses had closed, and the default rate among bond issuers was roughly 60\%. The Argentinean default rate severely negatively impacted commercial lenders (Boschi, 2005). It is important to note that 9/11 also had important financial implications during the mentioned years.

\subsubsection{7-2009 American Global Financial Crises}

The 2007-2009 American financial crises rapidly reached most of the world. It was considered the worst crises since the Great Depression. It had its origins on flawed mortgage-backed securities (MBSs), as explained before, that major American investment banks issued, overleveraging their operations. This situation is relevant because American investment banks sold such assets globally. This situation created an asset bubble in the American housing market, causing bond defaults across the country; initially with the subprime mortgages and later spreading to the entire MBS market. Because, since the 1990s, the entire global financial system grew interconnected, allowing the selling of securities globally. These junk securities, which unethically received AAA ratings from the rating agencies, were mainly sold to Japanese and European investors, where Greece, Ireland and Portugal were hit hardest. Throughout the crises, several American and European global investment banks were compromised (Reinhart \& Rogoff, 2008).

\subsubsection{Russian Financial Crisis}

The Russian economy grew substantially during the first years of the 21st century due to the rise of commodity prices, especially the increase of those in its energy sector. For this reason, the Russian's economy became dependent on exports, mainly oil and natural gas. However, when the global oil prices dropped nearly $40 \%$, Russia could no longer finance its budget. This situation negatively impacted the currency exchange of the Russian ruble; scaring away many foreign financial investors. In an attempt to finance its deficit, Russia expanded its monetary base, producing a high inflation rate, followed by interest rates increases; compromising Russian banks and their financial assets. The problem worsened when Russia invaded and annexed Crimea and Ukraine, resulting in American and European economic sanctions, including cutting off financial resources to Russia (Kuepper, 2018). 


\subsection{The Mexican Banking System}

As is commonly known, the main function of banks is to act as a financial intermediary; linking those who have a financial surplus with those who have a financial deficit. Banking institutions capture financial resources, in the form of savings, from the economy and channel those monies, in the form of financing or credits, towards individuals and/or companies that generate value added to the economy. Without banks, as financial intermediaries, economies would grow at lower rates. Efficiencies would also be compromised (Hoshi et al., 1990). The Mexican banking system competitiveness and efficiency is important because it provides the needed resources to foster the economy.

The Mexican banking system had its origins in 1864 when the Bank of London, México and South America opened its doors (Turrent, 2018). Several other banks were incorporated between 1875 and 1888 throughout the national territory but mainly in the Chihuahua and Yucatan states, and México City (Turrent, 2018). Even during the revolutionary period, banks operated within the national territory but it was until the mid 1920s that local banks got back on their feet. Another relevant aspect of the Mexican banking system is that all privately held banks were expropriated in 1982 and re privatized during the Salinas and De La Madrid administrations. Throughout its history, the banks' equity has switched from local to foreign; however, there is no reference that specifically specifies the country of origin of the capital of the banks operating in México, neither the percentage of foreign capital, but according to Turrent (2018), by 2003 over $80 \%$ of the net worth of the banks operating in México had foreign capital.

During 2016, according to National Baking and Stock Commission of Mexico $1 \ddagger$ (CNBV, 2016), the sector was incorporated by 47 institutions. Table 1 lists the main eight banks operating in México and the rest of the banking system. It is sorted by assets and based on the information provided by the CNBV. It depicts that only 4 banks hold assets over one million of million Mexican pesos, nine between 100,000 and less than 1,000,000, millions of pesos, and the reminding 34 hold assets under 100,000 millions of Mexican pesos. Also, it is important to notice that not all the banks have the same operational range; some are national while others are mainly regional. Furthermore, some are actual financial intermediaries while others are the financial arm of a store, supermarket, or car company. This characterization of the banks operating in México is not homogeneous at all and explains the system concentration.

Insert Table 1 here.

Table 2 summarizes each of the eight main institution's major financial information; total assets, equity, sales, and net income - but presented as a percentage of the total banking system. As you can see, this is a highly concentrated sector; bigger

\footnotetext{
${ }^{1}$ The Comisión Nacional Bancaria y de Valores (CNBV) mission and vision are: Supervise and regulate the entities of the Mexican financial system, to ensure its stability and proper operation. The CNBV has, as well, to maintain and promote a healthy and balanced development of the whole system, protect the interests of the public, and act as an efficient, modern and respected authority that seeks the stability of the Mexican Financial System. This has to be accomplished according to best international practices, contributing to build a prosperous Mexico, where every family has access to more and better financial services. The scope of its operations allows it to supervise brokerage houses, development banks, banks, and mutual funds.
} 
banks concentrate larger proportion of total assets, shareholders' equity, sales, and net income.

Table 1

Financial Information of the Main Eight Institutions and the Rest of Banks

\begin{tabular}{lccrr}
\hline \multicolumn{1}{c}{ Bank Name } & $\begin{array}{c}\text { Total } \\
\text { Assets }\end{array}$ & $\begin{array}{c}\text { Stockholders' } \\
\text { Equity }\end{array}$ & $\begin{array}{c}\text { Sales/ } \\
\text { Turnover }\end{array}$ & $\begin{array}{c}\text { Net } \\
\text { Income }\end{array}$ \\
\cline { 2 - 5 } (Millions of Mexican Pesos) \\
\hline 1. BBAV Bancomer & $1,908,681.0$ & $158,982.4$ & $137,878.7$ & $33,311.4$ \\
2. Santander & $1,373,514.5$ & $107,290.4$ & $76,972.9$ & $15,749.9$ \\
3. CitiBank Banamex & $1,118,622.1$ & $152,207.7$ & $90,162.7$ & $10,607.3$ \\
4. Banorte & $1,030,434.8$ & $92,786.6$ & $69,407.0$ & $15,044.4$ \\
5. HSBC & $652,014.4$ & $51,423.0$ & $34,605.8$ & $1,174.5$ \\
6. Banco Inbursa & $412,373.0$ & $90,651.1$ & $27,229.1$ & $7,876.0$ \\
7. Scotiabank & $380,881.8$ & $41,214.9$ & $24,572.3$ & $4,372.6$ \\
8. Interacciones & $202,414.8$ & $13,689.4$ & $11,089.5$ & $2,403.6$ \\
\hline Rest of the Banks & $1,593,165.4$ & $150,977.4$ & $167,561.1$ & $16,722.7$ \\
(39 institutions) & \multicolumn{4}{c}{} \\
\hline Bank System & $8,672,101.8$ & $859,222.9$ & $639,479.1$ & $107,262.4$ \\
\hline Sources: the information at December 31, 2016 is provided by the CNBV and the calculations \\
are ours. The information on this table offers a different depiction than the one \\
$\quad$ offered by income and expenses; which is the one we will be using for the sticky cost \\
analysis. Furthermore, it is important to notice that the first eight are commercial \\
banks; even though, as previously mentioned, there are more commercial banks, but \\
not all institutions are commercial banks.
\end{tabular}

Table 2

Major Financial Indicators of the Main Institutions versus The Rest of The Banking System

\begin{tabular}{lrrrr}
\hline \multicolumn{1}{c}{ Bank Name } & $\begin{array}{c}\text { Total } \\
\text { Assets }\end{array}$ & $\begin{array}{c}\text { Stockholders' } \\
\text { Equity }\end{array}$ & $\begin{array}{c}\text { Sales/ } \\
\text { Turnover }\end{array}$ & $\begin{array}{c}\text { Net } \\
\text { Income }\end{array}$ \\
\hline 1. BBAV Bancomer & $22.0 \%$ & $18.5 \%$ & $21.6 \%$ & $31.1 \%$ \\
2. Santander & $15.8 \%$ & $12.5 \%$ & $12.0 \%$ & $14.7 \%$ \\
3. CitiBank Banamex & $12.9 \%$ & $17.7 \%$ & $14.1 \%$ & $9.9 \%$ \\
4. Banorte & $11.9 \%$ & $10.8 \%$ & $10.9 \%$ & $14.0 \%$ \\
5. HSBC & $7.5 \%$ & $6.0 \%$ & $5.4 \%$ & $1.1 \%$ \\
6. Banco Inbursa & $4.8 \%$ & $10.6 \%$ & $4.3 \%$ & $7.3 \%$ \\
7. Scotiabank & $4.4 \%$ & $4.8 \%$ & $3.8 \%$ & $4.1 \%$ \\
8. Interacciones & 0.02 & 0.02 & 0.02 & 0.02 \\
\hline Total & $81.6 \%$ & $82.4 \%$ & $73.8 \%$ & $84.4 \%$ \\
Rest of the Banks & $18.4 \%$ & $17.6 \%$ & $26.2 \%$ & $15.6 \%$ \\
Total Bank System & $100.0 \%$ & $100.0 \%$ & $100.0 \%$ & $100.0 \%$ \\
\hline Sourcs: & & &
\end{tabular}

Sources: the information at December 31, 2016 is provided by the CNBV and the calculations are ours.

To highlight this concentration is important because it proves Auletta (2015) point that larger equity attracts larger sales. BBAV Bancomer has the largest equity and the largest sales volume. It is closely follow by CitiBanamex that holds the second largest equity balance and the second largest sales volume, even though it holds the third largest asset volume; Banco Santander has more assets than CitiBanamex but not sales. The provided information depicts a heterogeneous sector, in which the eight 
largest institutions centralize assets, equity, sales, and net income; monopolizing over $81 \%, 82 \%, 73 \%$ and $84 \%$ of total assets, equity, sales, and net income, respectively, of the sector's financial resources.

Part of its high concentration, has to do with its most current background, specifically with its 1982 expropriation and a later re privatization. During the government's bank ownership, banks were restructured; situation that provoked at least partially the sector concentration (Turrent, 2018). The largest banks also present an important trend of mergers and acquisitions; mainly from foreign institutions. Also notice that the number of banks that operated in México during 2016 represents a tiny number, almost $1 \%$, in relation to the number of banks operating in the United States $2 . s$

During 2016, three new financial institutions started operations in México: Banco Sabadell , Banco Finterra, and the Industrial and Commercial Bank of China (CNBV, 2016).

\section{RESEARCH METHODOLOGY}

\subsection{Research Interest}

This research paper is interested in fostering the discussion about studying the effects of increases or decreases on income on banks' expenses. As an additional contribution to the specialized literature, we are also interested in reviewing if these income/expense relationships are dependent on the number of previous years with an income increase or decrease, since it would be expected that in income decrease years there would be a lower "sticky factor" than in years with income increases. The hypotheses that are intended to demonstrate are:

$\mathbf{H}_{1}$ : the increase in selling and administrative spending is positively related to the income increase of Mexican banks, in years with an increase in income.

$\mathbf{H}_{2}$ : the increase in selling and administrative expenditure is positively related to the income increase of Mexican banks, in years with a decrease in income.

$\mathbf{H}_{3}$ : the ratio of the increase in selling and administrative expenses to the increase in income, in the years with a decrease in income, is lower than in the years with an increase in income.

\subsection{Method}

\subsubsection{Criteria Selection Database for Participating Banks:}

We based our analysis on the information provided by the $\mathrm{CNBV}^{* * 3}$. We downloaded 16 electronic files; 15 of which were Microsoft's Excel documents and one was a PDF file. These files had the information of all the banks operating in México from 2001 to 2016. It is important to mention that we based our analysis on the banks and subsidiaries, not on the financial groups' information to which the bank might belong to. Likewise, there could have been complements to the information provided by the CNBV and if that is the case, the complementary information was not considered in the present analysis; the bulletins present the statistical and financial information of the entities for the Mexican banking system, as available on the date of its preparation, December 31, of the years 2001 to 2016, and later filling.

\footnotetext{
${ }^{2}$ According to the press release of the FDIC (2016), there were approximately 4,800 banks and savings associations operating the United States by the end of 2016.

3 The CNBV (2017a), in México, or National Baking and Stock Commission of Mexico, is a self-governing agency of the Secretariat of Finance and Public Credit. It has decision-making powers over the Mexican financial system.
} 
Business cycle fluctuations have always been a challenge for management, due to profitability, financial safety and strength reasons (Albertazzi \& Gambacorta, 2009). This is especially the case for banks; banks' business cycle is linked to macroeconomic circumstances; this is because "bad debts, provisions, and loan losses" usually happen during bearish markets (Quagliariello, 2007). In México, local and external conditions including political turmoil, changes in the external commercial arrangements (NAFTA), and internal and/or external financial crises, among others might have an important negative effect on banks' performance, income and expenses, along with the negative effect on their assets. It is the management's and authorities' responsibility to ensure banks comply with the current legislation, its financial intermediation responsibilities, and that are adequately managed.

This is especially important during economic downturns because there can be negative repercussions, such as interest rate increases and other related risks, lower loan portfolio quality, portfolio defaults, credit losses, and therefore reduced profitability (Albertazzi \& Gambacorta, 2009). That is why it is important to constantly monitor the income and expense levels of the local banks, especially during disruptive circumstances, such as the examples of crises recently provided, to see if they are behaving linked appropriately. The income level will allow us to verify if the bank's activities are expanding or contracting, while focusing on the expense level will tell us if the income and expense levels are appropriately coordinated to offer support for the extra demand or if there is an excessive level of expenses for certain level of income, at a determinate period. Adequate coordination between income and expenses will foster profitability, financial safety, and strength. On the other hand, an inadequate income expense ratio represents a risk that is further impacted negatively by expense stickiness that will produce lower profitability, financial danger, and weakness in the banking system and individual institutions, along with the negative effects on the banks' portfolio.

The CNBV information allowed us to sort the banks according to total assets, stockholder's equity, sales and net income, as previously stated. It, as well, allowed us to rank them based on different types of credit portfolios. It is important to highlight that regardless of the criteria used, the set of selected banks would have been the same. For these reasons, we can establish that our criterion for banking selection was total assets. Yet, we also considered the concepts mentioned, including their credit portfolio.

\subsubsection{Selected Institutions}

The eight banking selected institutions were: a) BBVA Bancomer, b) Santander, c) Citibank Banamex, d) Banorte, e) HSBC, f) Scotiabank, g) Inbursa, and h) Interacciones. The selected banks for the current sticky cost analysis were the main eight players at the Mexican financial market during 2016. Even though the players partially changed over time; depending on the selected criteria, we decided to base our analysis on the current ones-regardless of the relatively long period of analysis, 16 years - from 2001 to 2016. The criterion used was the size of the total assets and credit portfolio including business, financial institutions, and governmental entities. Both independent criterions helped to select the same banks. If we would have used shareholders' equity, sales, or net income, the selected banks would have been the same but for Interacciones. Banco del Bajio's equity is larger than the one presented by Interacciones.

These eight banks concentrate over 4 times more assets and stockholders equity, almost 3 times more sales, and over 5 times more net income than the rest of the banks. Additionally, it is noticeable that the rest of the banks, 39 institutions, are not as 
large as the largest bank but when talking about sales. This concentration is what characterizes the Mexican banking system.

Now in terms of total credit portfolio, these eight selected banks had a total credit portfolio of $\$ 3,932,722$ million pesos during 2016, which represented over $85 \%$ of the total credit granted in Mexico that year ${ }^{4}$. These same banks had over $81 \%$ of the business credit portfolio; with a total of $\$ 1,607,702$ million pesos granted ${ }^{5}$. In relation to the loan portfolio to financial institutions, the selected banks represent almost the $79 \%$ of the total awarded to these institutions, or $\$ 149,428$ million pesos ${ }^{6}$. Finally, $\$ 443,400$ million pesos was the loan portfolio to government entities representing almost the $76 \%$ of the total to these entities ${ }^{7}$.

The eight most representative banks in the Mexican economy during the 20012016 period are showed in Table 3. With this table we wanted to show (in the years 2001, 2005, 2011, and 2016) the relative ranking of banks among themselves. We can see that Bancomer leadership was not challenged in these particular years. Santander moved ahead of Banmex and Banorte topped HSBC by 2016. Imbursa throughout this period has been between the eighth and sixth place; just to mention some examples of their relative ranking throughout the mentioned period.

\section{Table 3}

\section{Eighth Banking Selected Ranking}

\begin{tabular}{cllll}
\hline Rank. & \multicolumn{1}{c}{ 2001 } & \multicolumn{1}{c}{ 2005 } & \multicolumn{1}{c}{ 2011 } & \multicolumn{1}{c}{ 2016 } \\
\hline 1. & Bancomer & Bancomer & Bancomer & Bancomer \\
2. & Banamex & Banamex & Banamex & Santander \\
3. & Serfin & Santander Serfín a & Santander b & Banamex \\
4. & Bital & HSBC c & Banorte d & Banorte \\
5. & Santander Mexicano & Mercantil del Norte & HSBC & HSBC \\
6. & Mercantil del Norte & Scotiabank Inverlat & Inbursa & Scotiabank \\
7. & Scotiabank Inverlat & Inbursa & Deutsche Bank & Inbursa \\
8. & Inbursa & Del Bajío & Scotiabank e & Interacciones \\
\hline
\end{tabular}

Source: own elaboration. Cooperative historical evolution ${ }^{8}$. Ht

As can be seen, six banks have been the regular main players in the selected period, especially in the four selected years: BBVA Bancomer, CitiBanamex, SantanderSerfin, Bital-HSBC, Banorte, and Inbursa. Banco del Bajío, Deutsche Bank and Interacciones appeared sometimes during the selected years, other banks had also made the "big eight" in particular years.

\subsubsection{Information's Integration Complexity}

\subsubsection{Accounting Accounts Complexity}

Throughout the performed analysis, 16 years, the CNBV's income statement format changed a few times. The lack of uniformity made the analysis complicated and prone to errors, because the number of concepts included within the income statement changed and because the ways in which expenses were displayed also changed. For the

4 The information is provided by the CNBV (2017b) and the calculations are ours.

5 The information is provided by the CNBV (2017b) and the calculations are ours.

6 The information is provided by the CNBV (2017b) and the calculations are ours.

7 The information is provided by the CNBV (2017b) and the calculations are ours.

8 Cooperative historical evolution: Serfin and Santander Mexicano merger into Santander Serfin. Later Santander Serfin changed its name to Santander. CitiBank purchased Banamex. Bital was purchased by HSBC. Mercantil del Norte changed its name to Banorte. Scotiabank bought Inverlat and then changed its name to Scotiabank. 
present analysis, we required to compare income to expenses, but not all the time other expenses were included in the administration and promotion expenses. We had to move the data so that the amounts provided would be aligned as income and expenses; at the end of this process, we had only three aligned lines presenting net income, administrative and selling expenses, and other expenses, when applicable. For the analysis itself, we compared income to expenses, all expenses included, exclusively. The rest of the information provided by the CNBV was not included in the analysis because it was not relevant for the sticky cost analysis that we wanted to perform.

\subsubsection{Other Accounting Issues}

It is important to mention that not all the required information was included in downloaded files; we had to estimate income and expenses several times through a series regression. We verified which provided information was statistically considered as an outlier to ensure that the information used was correct.

\subsubsection{Mergers' Complexity}

The number of mergers and acquisitions, within the Mexican banking system, also complicated the analysis because we had to make sure that acquired institutions included all the parts, throughout the complete 2001-2016 period. For instance, HSBC bought Vital, so we had to consider both entities, during the relevant years, to make sure that the income and expenses were complete throughout the 16-year analysis period. Another example is Santander. This was done to make sure that increases or reductions on the income were somehow replicated by the expenses, considering both the acquiring and acquired institutions. If we would have not done it, we would have lost some years analyzing the actual correlation between income and expenses for the banks that went through mergers and/or acquisitions. Additions to the number of banks working in the Mexican market were easier to deal with because we did not have to track potential complements to the information. There were also changes to the bank name that we followed to make sure that it was only that. Due to the mergers complexity and other related issues, two academic doctors reviewed the information and did the integration separately to compare differences and match criteria.

\subsection{Size of the Sample}

We selected eight banks for our analysis and tracked their performance for 16 years, from 2001 to 2016; linking both income and expenses. The information of eight banks times 16 years results in a total of 128 sets of data. However, since we need to keep track of the changes, we ended up with 120 sets of data.

\subsection{Database Construction}

In order to obtain the transversal nature of the data, for 16 years, we had to obtain, move, and statistically make sure that the data sets were accurate, and perform the statistical analysis with the information filled, at the CNBV, by each bank and its subsidiaries and/or merged banks that was consolidated annually. As we mentioned before, we had to move around some information. For example, the income of Bancomer individually was added to the income of Bancomer servicios; the income of Santander individually was added to the Serfin's income, which was an acquired bank; the income of Banorte individually was added with Ixe's income; HSCB income was added to Bital's income, which was an acquired bank. The same was done for the respective expenses during the relevant years.

With respect to the information not included in the field, by the banks at the CNBV, four "missing data" sets were identified $(3.125 \%$ out of the total data): Banorte did not present information for 2001, Ixe for 2003, Inbursa for 2001 and 
Interactions for 2013. For these purposes, different methods have been developed and used for this type of situations. The use of this treatment involves a decision, whether discarding the missing data cases or using some estimation method. The decision depends on factors such as the sample size, the number of missing cases and whether the missing data is non-systematic (McKnight et al, 2007). Furthermore, if the decision taken involves estimating the missing data, there are a few options as well. Replacing the missing values with the averages of the variables is a possibly method; however, it can cause problems by moving the sampling distributions away from their natural channel. However, when the values of other variables are known and available, a method of estimating the missing values can be the regression method; using the available variable with the highest absolute correlation (Frane, 1976). Taking into consideration these authors, for the present research paper, we decided to estimate the missing data; we used linear regression equations to calculate the missing numbers from the time trends of the bank's data.

\subsection{Analysis}

The analysis' sample is made up of the information of the 8 largest banks in Mexico, for 16 consecutive years, which generates a database of 120 samples ( 8 banks $\mathrm{x}$ 16 years, gives a sample of 128 , but one year is lost by working with incremental rates).

This research is not only interested in forecasting the rate of increase or decrease on expenses, based on the rate of increase or decrease on income, but also to review whether these relationships depend on whether the previous year presented an income increase or decrease. For this reason, we introduced a dummy regression variable. The variables of the banks will be identified as follows:

a) Change in the level of administration expenses

$\rightarrow$ Delta_EX $\mathbf{X}_{\mathrm{t}+1}=\left(\mathbf{E X}_{\mathrm{t}+1-\mathbf{E X}} \mathbf{E}\right) / \mathbf{E X}_{\mathbf{t}}$

b) Change in the income level $\rightarrow$ Delta_IN $\mathbf{I N}_{\mathbf{t}+1}=\left(\mathbf{I N}_{\mathbf{t}+1}-\mathbf{I N}_{\mathbf{t}}\right) / \mathbf{I N}_{\mathbf{t}}$

c) An a dummy variable $\rightarrow \mathrm{D}=1$ years with income increase, or $\mathrm{D}=0$ years with income decrease.

For the first hypothesis, the increase in administrative spending is positively related to the income increase of Mexican banks, in years with an increase in income, is equivalent to prove $\mathrm{H}_{1}: \mathrm{B}_{1} \neq 0$. For the second hypothesis, the increase in administrative expenditure is positively related to the income increase of Mexican banks, in years with an income decrease, is equivalent to prove $\mathrm{H}_{2}: \mathrm{B}_{2} \neq 0$. Finally $\mathrm{H}_{3}$, the third hypothesis, the ratio of the increase in administrative expenses to the increase in revenues, in the years with a decrease in income, is lower than in the years with an increase in income, is equivalent to prove $\mathrm{H}_{3}: \mathrm{B}_{2}<\mathrm{B}_{1}$. All in the analyzed regression model:

Delta_EX $\mathbf{X}_{\mathrm{t}}=\mathbf{B}_{0}+\mathrm{B}_{1} * \mathrm{D} *$ Delta_IN $\mathrm{I}_{\mathrm{t}}+\mathrm{B}_{2} *(1-\mathrm{D}) *$ Delta_IN $\mathrm{I}_{\mathrm{t}}+\mathrm{e}$

\section{FINDINGS}

In the financial statements of the 8 banks, for 16 consecutive years, from 2001 to 2016 ( $n=120)$, see Table 4 where the following statistics are observed:

Insert Table 4 here.

As you can see, the eight banks during the selected 16 years have an average annual increase in administrative expenses of $10.41 \%$, which is greater than the annual average income of $8.8 \%$. However, it is important to notice that that the expense increases vary depending on whether there were years with income increases or years with income decreases. Theoretically speaking, it would make sense that income increases should be followed by expense increases and that income decreases should be 
followed by expend decreases, but this does not happened. In the years with income increases, annual expenses increase on average $12.67 \%$ (see red line on Table 4), but on the years with income decreases, expenses, on average, increased by $5.34 \%$ annually (see blue line on Table 4).

\section{Table 4}

Descriptive Statistics from the Mexican Banks

\begin{tabular}{|c|c|c|c|c|c|}
\hline Annual change & $\mathbf{N}$ & Mean & StDev & Maximum & Minimum \\
\hline Income & 120 & $8.80 \%$ & $18.22 \%$ & $89.48 \%$ & $-34.28 \%$ \\
\hline $\begin{array}{l}\text { In years with income } \\
\text { increase }(D=1)\end{array}$ & 83 & 17.03 & 17.74 & 0.37 & $89.48 \%$ \\
\hline $\begin{array}{l}\text { In years with income } \\
\text { decrease }(D=0)\end{array}$ & 37 & -9.68 & 8.69 & -34.28 & -0.08 \\
\hline Expenses & 120 & $10.41 \%$ & $19.83 \%$ & $119.17 \%$ & $-22.26 \%$ \\
\hline $\begin{array}{l}\text { In years with income } \\
\text { increase }(D=1)\end{array}$ & 83 & $12.67 \%$ & $17.88 \%$ & $119.17 \%$ & $-20.28 \%$ \\
\hline $\begin{array}{l}\text { In years with income } \\
\text { decrease }(D=0)\end{array}$ & 37 & $5.34 \%$ & $18.21 \%$ & $83.36 \%$ & $-22.26 \%$ \\
\hline
\end{tabular}

Source: own elaboration.

When we decided to analyze two consecutive years of the income - expense ratio, of the eight selected banks during the selected 16 years, we had to adapt the number of observations to the new number of records. Since we needed to calculate annual increments, we lost 16 sets of information from the original sample of 128 , because by subtracting two years for the number of selected banks (eight banks times two years $=16)$; we ended up with 112 records $(128-16=112)$. From this new sample, we got that 57 cases $(50.9 \%)$ achieved two consecutive income increase years, 42 cases $(37.5 \%)$ had one income increase or decrease year, and 13 cases $(11.6 \%)$ that had two consecutive income decrease years. This is actually very important because it was only during these regional/global financial crises that the selected banks actually reduced their expense levels; during the rest of the analysis period, banks continue expanding their expenses but at a lower rate. From our perspective, the only logical reason why this happened is because management thought that the medium and long term perspectives had changed. These two years of prolonged income decreases correspond to the Argentinean and American crisis' effects, during this century. The Mexican banks cut importantly their expense levels during 2002-2003 and 2009-2010. In general terms, banks with two consecutive income increase years had on average an $18.58 \%$ annual income increase, while their average expense grew annually at an average of $12.48 \%$. On the other hand, during the two consecutive income decrease years, banks annual income decreased on average $-7.53 \%$; during the second year of income decrease, banks' spending grew on average $10.27 \%$. This situation does not happen all the time, or does this applies to all banks. It is also worth mentioning that when it happens, it does with certain delay relative to the causing crisis.

It is important to remember that the $9 / 11$ events unleashed a global crises that was felt globally, which among many other effects, there was reduced liquidity levels and negatively impacted the local banking system. Some of the same effects were present during the 2008 financial crisis. These abnormalities or man-made crises are not common events. 
Figure 1

Analysis between Delta Income vs. Delta Expenses Swapped in between Good (Income Increase) and Bad (Income Decrease) Years

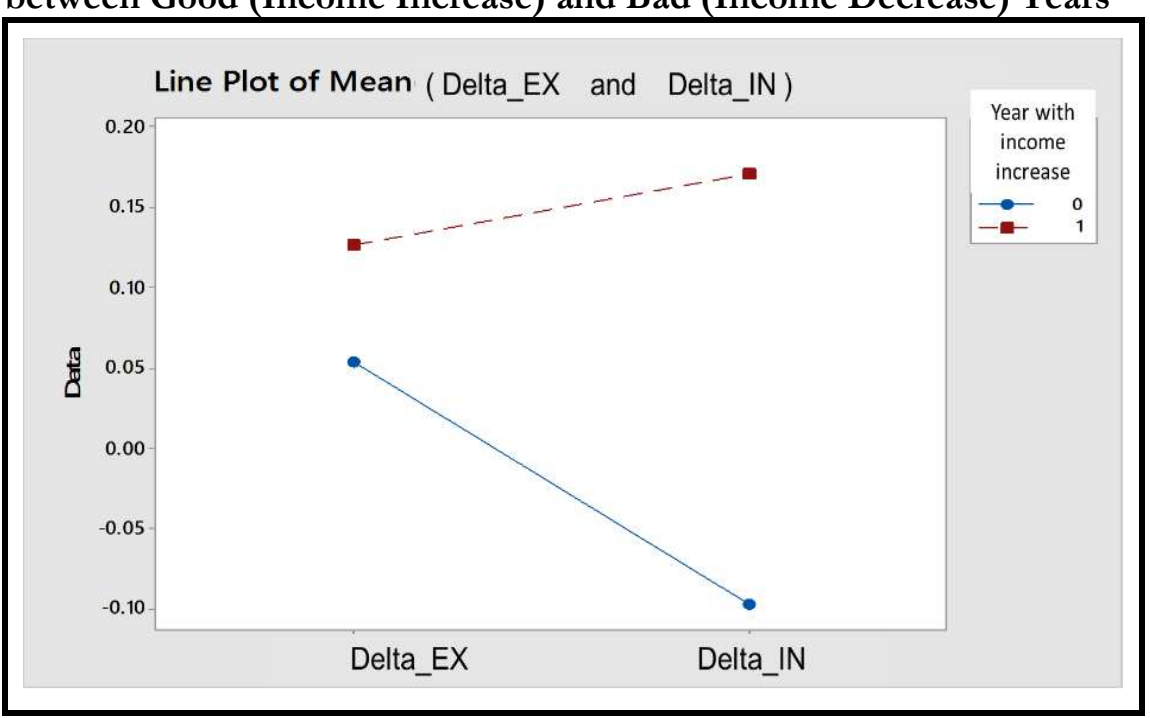

Source: own elaboration.

In this period, it is worth highlighting two extreme cases in terms of annual expenses: a) a bank reduced its spending by $-22.26 \%$ in one year; b) and another bank increased its expenses from one year to the next by $119.17 \%$. The correlation results, between the variables, are presented in Table 5.

Table 5

Pearson Correlation between Annual Incomes-Expenses, Differentiation the Kind of Year

\begin{tabular}{lc}
\hline \multicolumn{1}{c}{ Annual Income Increase } & Annual Increase Expenses \\
\hline In Every Single Year & 0.319 \\
$(\mathrm{~N}=120)$ & $(0.000)$ \\
In Years with Increase in Income & 0.321 \\
$(\mathrm{D}=1, \mathrm{~N}=83)$ & $(0.003)$ \\
In Years with Income Decrease & 0.059 \\
$(\mathrm{D}=0, \mathrm{~N}=37)$ & $(0.729)$ \\
\hline
\end{tabular}

Source: our own elaboration. Cell contents: in the upper value, the Pearson correlation, in parenthesis, the P-value.

The observed correlation between the annual increase in revenues and the annual increase in expenses, in Mexican banks, is significant and moderate ( $r=0.319, \mathrm{P}$ value $<0.001$ ); corresponds to the academic theory, where to a higher income corresponds higher expenses. But surprisingly enough, the relationship between income and expenses during good years, income increase years, are separated from bad years, income decrease years, does not perform in the same way. There is a significant and moderate relationship between income and administrative expenses, in years with an income increase $(r=0.31, P$-value $<0.001)$, but there is a weak and non-significant relationship between income and expenses, in the income decrease years $(r=-0.059, \mathrm{P}-$ value $<0.729)$. Now, the regression analysis results, taking the increase in expenditures as a criterion variable are the shown in Table 6. 
Table 6

Variance Analysis

\begin{tabular}{|c|c|c|c|c|c|}
\hline Source & $\overline{d f}$ & Adj. SS & Adj. MS & F-Value & P-Value \\
\hline Regression & 2 & 0.41184 & 0.20592 & 6.81 & 0.002 \\
\hline $\begin{array}{l}\text { Years of Income } \\
\text { Increase }(D=1)\end{array}$ & 1 & 0.32136 & 0.32136 & 10.62 & 0.001 \\
\hline $\begin{array}{l}\text { Years if Income } \\
\text { Decrease }(D=0)\end{array}$ & 1 & 0.01025 & 0.01025 & 0.34 & 0.562 \\
\hline Error & 117 & 3.53961 & 0.0302 & & \\
\hline Total & 119 & 3.95145 & & & \\
\hline Model Summary & & $\begin{array}{c}\mathbf{S} \\
0.173934\end{array}$ & $\begin{array}{c}\text { R-Sq } \\
10.42 \%\end{array}$ & $\begin{array}{c}\text { R-sS (adj) } \\
8.89 \%\end{array}$ & \\
\hline Term & Coef. & SE Coef. & T-Value & P-Value & VIF \\
\hline $\mathrm{B}_{0}$ Constant & 0.0698 & 0.0226 & 3.09 & 0.003 & \\
\hline$B_{1}$ by $D=1$ & 0.329 & 0.101 & 3.26 & 0.001 & 1.12 \\
\hline $\mathrm{B}_{2}$ by $\mathrm{D}=0$ & 0.150 & 0.257 & 0.58 & 0.562 & 1.12 \\
\hline
\end{tabular}

Source: own elaboration.

Notes: the variance inflation factor $(\mathrm{VIF})$ is between 1 and $5(1<\mathrm{VIF}<5)$. It appears that multicollinearity does not represent a problem. The regression equation resulting after

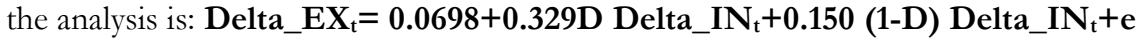

Figure 2

Ratio of Administration Expenses against Income

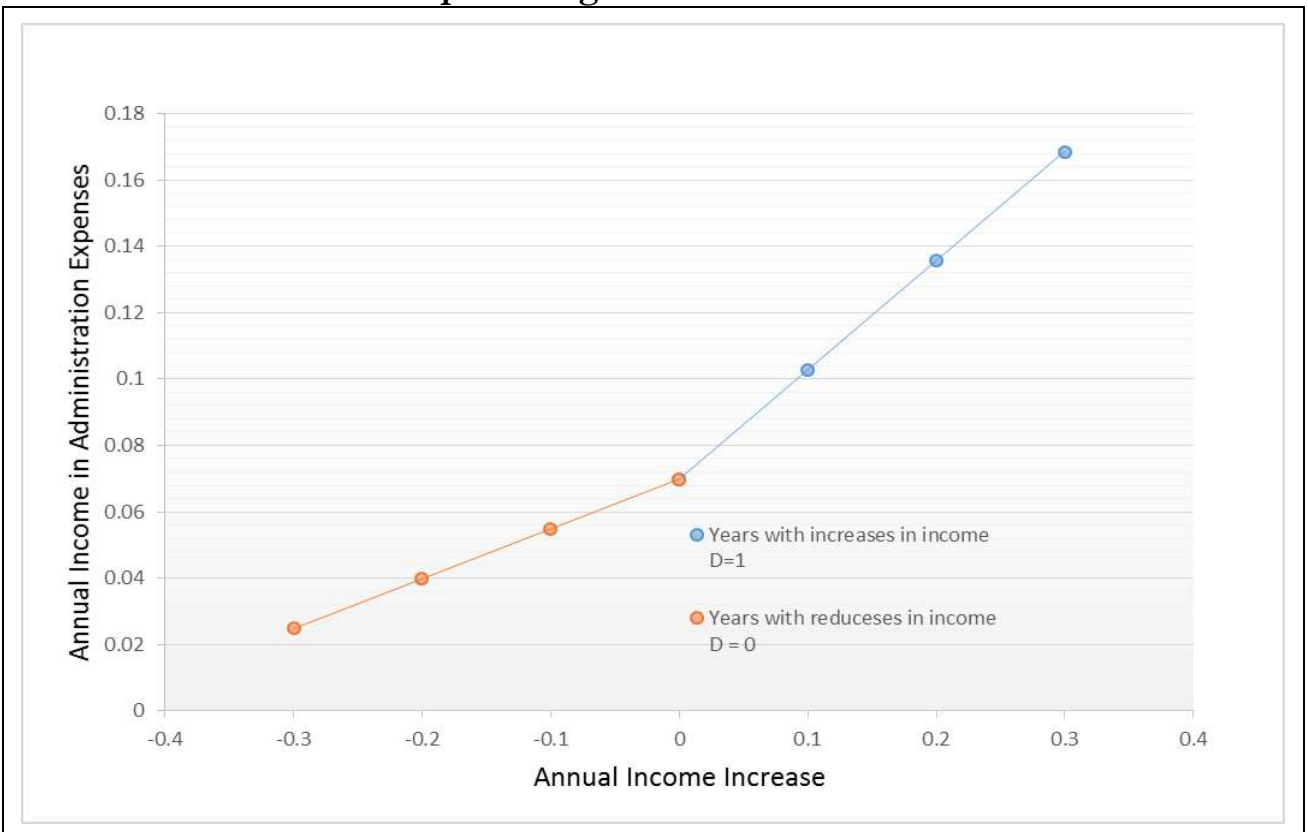

Source: own elaboration.

We also found that income increases or decreases have an unanticipated effect on the level of administrative, selling and other expenses. Theoretically speaking, we anticipated that an income increase will be supported by an expense increase and that income decrease will be followed by an expense decrease. Yet we found that absent of a global crises income increases were supported by larger expense levels and that income decreases were followed by reduced expense increases. In other words, during years 
described as good years when income increased, expenses grew faster; while during years described as bad years when income decreased, expenses continue to increase but a significantly lower rate. This means that the banks' bottom line will suffer due to the deceitful nature of the sticky costs, regardless of income increases or decreases - unless there is a global crisis. Another important finding is that an increased rate of expenses is different from an increase in years with income decreases.

\subsection{Results and Interpretation}

Based on the data and analysis above, we conclude the following about our three hypotheses. For $\mathrm{H}_{1}$ the hypothesis is confirmed in years with an income increase, since the income increase is a significant estimator to forecast expenses increases $\left(B_{1}=0.329\right.$, $\mathrm{P}$-value $\leq 0.001)$. In relation to $\mathrm{H}_{2}$, the hypothesis cannot be confirmed, since the result is not significant to forecast an expense decrease, from income decreases, for years with income decreases $\left(B_{2}=0.15\right.$, P-value $\left.=0.562\right)$. To test $\mathrm{H}_{3}, \mathrm{~B}_{2}<\mathrm{B}_{1}$, we will use the distribution $B_{1} \cdot t\left(B_{1}\right.$, SE Coef, $N-2=118$ degrees of freedom, alpha of $5 \%$, one tail), the critical decision value will be found in $\mathrm{VC}=0.329-1,658 \mathrm{x} 0.101=0.16152$, and since $\mathrm{B}_{2}=0.150$ is lower, there is a $95 \%$ confidence in approving the hypothesis, which implies that for Mexican banks, it is easier to raise administrative expenses in years of bonanza to a rate of 0.329 , than to lower them, in income decrease years at a rate of 0.150 .

\section{CONCLUSION}

Comparing our research results- even though our covers the Mexican commercial banks - with Anderson et al. (2003) and Calleja et al. (2005), we found that. The Mexican banks case showed a $0.329 \%$ expense increase per each $1 \%$ income increase, on income increase years. This is significantly lower than the results presented by Anderson et al. (2003) with a $0.97 \%$ increase, and Calleja et al. (2005) with a $0.55 \%$ increase. On the other hand, Mexican banks presented an expense decrement of $0.15 \%$ per each 1\% income decrease on income decrease years, compared with Anderson et al. (2003) with a $0.91 \%$ and Calleja et al. (2005) with a $0.35 \%$. Regardless of the country and type of industry, we reached the same conclusion: on income increase years expenses grow faster that the reduction rate presented on income decrease years.

Werbin (2011) reached several conclusions; her first conclusion was that costs are especially sticky on the short and medium term but not so much on the long term. She considered that this is the case due to managements' delayed actions and balancing unused capacity cost with cutting such cost and replacing them when appropriate. We do not believe in managements' negligence; yet, we believe in management's investing long term due to Mexico's potential. Stímolo and Luquez (2015) support this idea; explaining that management contract resources as best fit their expectations and that expense level changes are not automatic. In a way, management is creating a fixed expense substructure that when income increases will only require variable costs. As previously mentioned, it is through assets that businesses compete. It might be of dire need to create economies of scale, for instance, or for other competing strategies. Stímolo and Luquez (2015) describe the cost-volume-profit model that uses those same variables. That is why expenses show their stickiness. If the banks are purchasing real estate, the asset revaluation complement is also expected but outside the scope of the present research paper.

Another of Werbin's conclusions is related to the rigidity of the decreasing costs that the author pins on management's decisions, and not on the stickiness nature of 
costs. Werbin states that "sticky costs can be recognized and controlled" (2011). We concur that management is deliberately using assets that translate into expenses that cause stickiness; instead of using shorter term contracts and or outsourcing. As explained before, such assets allow banks to compete in the medium and long terms; management is beating on the long term potential of the Mexican banking system. It is crucial to highlight that the Mexican banking system, as of December 2016, had only $1 \%$ of the number of participants of the American banking systems.

Werbin's final conclusion relates to the positive relation between income and expenses when both increase yet expenses grow slower $(.59 \%$ for en $1 \%$ income increase). Since Werbin analysis only covered 2005 to 2007 there is not income decrease calculation for cost stickiness. We estimated that the average cost increase, during this 16 year period, was $10.41 \%$. This difference might have to do with the periods selected difference.

\subsection{Extension}

Using the same database, we now seek to find the regression coefficients, to relate the administration of expenses against two consecutive years of income increase, and the subsequent for two consecutive years of income decreases. For example, how much does spending increase, if you have two consecutive years of income increase? Or how much does expenditure decrease if there are two consecutive years of income decrease? Now, the sample size is reduced to $\mathrm{N}=112$, of the following variables:

$\mathrm{D} 1=1$, two years with consecutive income increase, $\mathrm{D} 1=0$ in other cases.

a) $\mathrm{D} 2=1$, the last year an income decrease and the previous an income increase, $\mathrm{D} 2=0$ in other cases.

b) $\mathrm{D} 3=1$, the last year an income increase and the previous an income decrease, D3 $=0$ in other cases.

c) $\mathrm{D} 4=1$, two years with consecutive income decrease, $\mathrm{D} 4=0$ in other cases.

The regression model that will be analyzed is

\section{Increase Expense $=B_{0}+B_{1} D_{1}$ Increase Income $+B_{2} D_{2}$ Increase Income + $\mathrm{B}_{3} \mathrm{D}_{3}$ Increase Income $+\mathrm{B}_{4} \mathrm{D}_{4}$ Increase Income $+e$}

\subsection{Future Research}

For future research, we suggest comparing the results of the study. In particular, the increase in expenses of $10.27 \%$, when there are two bad years, with the increase in administrative expenses of $5.34 \%$ when there is only one bad year. This comparison would help figure out why management doubles the expenses' level.

\section{REFERENCES}

Aaker, D. A. (1989). Managing assets and skills: The key to a sustainable competitive advantage. California Management Review, 31(2), 91-106.

Albertazzi, U., \& Gambacorta, L. (2009). Bank profitability and the business cycle. Journal of Financial Stability, 5(4), 393-409.

Anderson, M. C., Banker, R. D., \& Janakiraman, S. N. (2003). Are selling, general, and administrative costs "sticky"? Journal of Accounting Research, 41(1), 47-63.

Auletta, K. (2015). Greed and glory on Wall Street: The fall of the house of Lehman. New York: Open Road Media.

Balakrishnan, R., \& Gruca, T. S. (2008). Cost stickiness and core competency: A note. Contemporary Accounting Research, 25(4), 993-1006.

Boschi, M. (2005). International financial contagion: Evidence from the Argentine crisis of 2001-2002. Applied Financial Economics, 15(3), 153-163. 
Calleja, K., Steliaros, M. E., \& Thomas, D. C. (2005). Further evidence on the sticky behavior of costs. Cass Business School Research Working Paper. Retrieved November 21, 2018, from https://papers.ssrn.com/sol3/papers.cfm?abstract_id=688473.

Chopra, S., \& Sodhi, M. S. (2004). Managing risk to avoid supply-chain breakdown. MIT Sloan Management Review, 46(1), 53-61.

CNBV (2016). Información estadística y financiera de la banca a octubre de 2016. Comisión Nacional Bancaria y de Valores. Retrieved November 21, 2018, from https://www.gob.mx/cnbv/articulos/publica-cnbv-informacion-estadistica-yfinanciera-de-la-banca-a-octubre?idiom $=$ es

CNBV (2017a). ¿Qué hacemos? Comisión Nacional Bancaria y de Valores. Retrieved November 23, 2018, from https://www.gob.mx/cnbv/que-hacemos

CNBV (2017b). Portafolio de Información. Comisión Nacional Bancaria y de Valores. Retrieved November 23, 2018, from https://portafolioinfo.cnbv.gob.mx/ Paginas/Inicio.aspx.

Cooper, R., \& Kaplan, R. S. (1992). Activity-based systems: Measuring the costs of resource usage. Accounting Horizons, 6(3), 1-13.

FDIC (2016) Press Releases: Federal Banking Agencies Finalize Rule Expanding Number of Banks and Savings Associations Qualifying for 18-Month Examination Cycle. Federal Deposit Insurance Corporation. NR 2016-154. Retrived November 21, 2018, from https://www.occ.treas.gov/newsissuances/news-releases/2016/nr-ia-2016-154.html

Fisher, M. L., Hammond, J. H., Obermeyer, W. R., \& Raman, A. (1994). Making supply meet demand in an uncertain world. Harvard Business Review, 72(94302), 83-93.

Frane, J. (1976). Some simple procedures for handling missing data in multivariate analysis. Psychometrika, 41(3), 409-415. Http://dx.doi.org/10.1007/BF02293565

Gladwell, M. (2009). What the dog saw: And other adventures. Hachette UK: Back Bay Books.

Hoshi, T., Kashyap, A., \& Scharfstein, D. (1990). The role of banks in reducing the costs of financial distress in Japan. Journal of Financial Economics, 27(1), 67-88.

Kuepper, J. (2018, August 30). What caused the Russian financial crisis of 2014-2015 Retrieved November 21, 2018, from https://www.thebalance.com/what-causedthe-russian-financial-crisis-of-2014-and-2015-1979012.

McKnight, P., McKnight, K. Sidani, S., \& Figueredo, A. (2007). Missing data: A gentle introduction. New York, USA: The Guilford Press.

Milesi-Ferretti, G. M., \& Tille, C. (2011). The great retrenchment: International capital flows during the global financial crisis. Economic Policy, 26(66), 289-346.

Pagan, A. (2003). Report on modelling and forecasting at the Bank of England/Bank's response to the Pagan report Bank of England. Quarterly Bulletin, 43(1), 60-91

Porporato, M., \& Werbin, E. M. (2010). Active cost management in banks: Evidence of sticky costs in Argentina, Brazil and Canada. Management Accounting Section (MAS) Meeting Paper. Retrieved November 23, 2018, from https://ssrn.com/ abstract=1659228 or http://dx.doi.org/10.2139/ssrn. 1659228.

Porter, M. E. (1985). Competitive Advantage: Creating and sustaining superior performance. New York: Free Press.

Quagliariello, M. (2007). Banks' riskiness over the business cycle: a panel analysis on Italian intermediaries. Applied Financial Economics, 17(2), 119-138.

Ray, G., Barney, J. B., \& Muhanna, W. A. (2004). Capabilities, business processes, and competitive advantage: Choosing the dependent variable in empirical tests of the resource-based view. Strategic Management Journal, 25(1), 23-37. 
Reinhart, C. M., \& Rogoff, K. S. (2008). Is the 2007 US sub-prime financial crisis so different? An international historical comparison. American Economic Review, 98(2), 339-344.

Stímolo, M. I., \& Luquez, L. S. (2015). Causas del comportamiento asimetrico de los costos (costos pegadizos). XXXVIII Congreso Argentino de Profesores Universitarios de Costos; Cordoba, Argentina.

Turrent, E. (2018, May 4). A brief summary of banking in Mexico. Retrieved November 21, 2018, from http://www.anterior.banxico.org.mx/sistema-financiero/materialeducativo/basico/\%7BFFF17467-8ED6-2AB2-1B3B-CCE5C2AF0E6\%7D.pdf.

Werbin, E. M. (2011). Los costos pegadizos (sticky costs): Una prueba empírica en bancos argentinos. Revista Iberoamericana de Contabilidad de Gestión, 7(14), 1-9. 